\title{
Challenges of international market selection - the perspective of Mexican and Brazilian multilatinas
}

\author{
João Maciel \\ Católica Porto Business School, Porto, Portugal \\ Joanna Radomska \\ Wroclaw University of Economics and Business \\ Susana Costa e Silva \\ Católica Porto Business School, Porto, Portugal
}

\section{Introduction}

In the last decade, a different breed of challenger businesses and brands started to be seen on the world stage. New multinational companies (MNCs) began to emerge not from the United States, Europe or Japan, but from emerging countries such as China, Russia, Turkey, Brazil, and Mexico' ${ }^{1}$. While emerging multinational companies (EMNCs) from Asia have been researched by many authors and institutions, Latin American multinationals have not been deeply investigated $^{2}$. The focus on emerging multinational enterprises (MNEs) from emerging countries into a host country belonging to the same income group, with some similar cultural characteristics, although geographically distant, is potentially enlightening for the understanding of the internationalization process in the new

1 A. Chattopadhyay, R. Batra, A. Ozsomer, The New Emerging Market Multinationals - Four Strategies for Disrupting Markets and Building Brands, McGraw-Hill Education, New York 2012.

2 R.V. Aguilera et al., Multilatinas and the internationalization of Latin American firms, "Journal of World Business" 2017, vol. 52(4), pp. 447-460. 
millennium. Therefore, those companies are perceived as an interesting subset of emerging market multinationals. The current theories suggest that emerging market multinationals may behave differently from multinationals from developed markets ${ }^{3}$. However, a great deal of the emerging market MNE research has focused on firms from China, which is a vastly different context. As indicated by Guillen and Garcia-Canal ${ }^{4}$, the motives for vertical investments are quite easily understood. However, the horizontal ones are harder to explain mainly because of the intangible assets that are required and that are not possessed by the companies representing the group of emerging countries (or at least were of different type than those possessed by enterprises from rich economies). While most of the research on international business is based in the headquarters of MNEs located mostly in rich countries, only a few attempts have been made at looking at the subsidiaries and the recipient countries. That is the research gap we want to fulfill using the CAGE framework.

Latin American multinationals were denominated "Multilatinas" by CuervoCazurra ${ }^{5}$ and described as companies that were born in the Americas, in countries previously colonized by Portugal, Spain or France, and with added-value operations abroad. This paper will focus on the Mexican and Brazilian Multilatinas, since they represent the two largest economies in Latin America. More than half of the Multilatinas from the America Economia Top 100 ranking from 2017 are from Brazil and Mexico, which has an impact on the value of their total sales ${ }^{6}$. This research will study the internationalization patterns of $31 \mathrm{Mul}-$ tilatinas companies from Brazil and 26 from Mexico that belong to the ranking mentioned.

According to Casanova et al. ${ }^{7}$, Multilatinas expand first into neighbouring countries and afterwards to other locations on other continents. However, the reasons behind this are not clear. This research aims to explore the process of market selection expansion of Mexican and Brazilian Multilatinas. We will try to understand why these multinationals expand into bordering locations (e.g. the United States and Central American countries in the case of Mexican Multilatinas, and South American countries for Brazilian Multilatinas) at the beginning of their expansion

3 M. Guillén, E. García-Canal, The American Model of the Multinational Firm and the 'New' Multinationals from Emerging Economies, "Academy of Management Perspectives" 2009, vol. 23(2), pp. 23-35.

4 Ibidem.

5 A. Cuervo-Cazurra, Multilatinas, "Universia Business Review" 2010, no. 25, pp. 14-33.

6 America Economia, Rankings, 2017, https://www.americaeconomia.com/rankings (accessed: 1.02 .2020$)$.

7 L. Casanova et al., From Multilatinas to Global Latinas: The New Latin American Multinationals, IDB Working Paper Series, 2009, pp. 4-234. 
into foreign markets and which external factors contribute to their market selection. This means that among all the internationalisation decisions, we will only focus on the market selection.

\section{Literature review}

Multilatinas are a specific case of EMNC - "companies born in the Americas, in a country previously colonized by Portugal, Spain or France and have added value operations abroad" 8 . As indicated by Guillén and García-Canal ${ }^{9}$, it is worth investigating that type of companies, as their conditions for development were totally different than those used by enterprises originating at rich economies. Most authors have defined Multilatinas as Latin American companies with operations in two or more countries.

One of Casanova's" findings was that Multilatinas first expand to their "natural markets", such as neighbouring Latin American countries, or the United States for Mexican companies, as Hispanic immigrants have been a crucial market for Multilatinas. This goes in line with Johanson and Vahlne ${ }^{11}$ Uppsala model of internationalization in an incremental and gradual manner.

Before expanding to new geographies, many Mexican and Brazilian Multilatinas were small, local family-owned businesses, while others due to governmental intervention were state-owned monopolies. Protectionist policies from the Brazilian and Mexican governments allowed Multilatinas to retain their market share and prevent foreign companies from competing with them in their local markets. Due to the size of the Brazilian and Mexican public sectors, these countries generated several state-owned Multilatinas. Unlike their European counterparts, investments, employment and sales are deeply anchored to the Brazilian and Mexican state legacy, which permitted very profitable businesses ${ }^{12}$. The strong leadership of Multilatinas and their willingness to take risks were very important, first to their natural markets (the United States and Central America for Mexican companies and South America for Brazilian companies) and then to more distant geographies such as Europe

8 A. Cuervo-Cazurra, Multilatinas, p. 16.

9 M. Guillén, E. García-Canal, The American Model...

10 L. Casanova, Global Latinas: Latin America's Emerging Multinationals, Palgrave Macmillan, London 2009.

11 J. Johanson, J. Valhne, The Internationalization Process of a Firm - a Model of Knowledge, Foreign and Increasing Market Commitments, "Journal of International Business Studies" 1977, vol. 8(1), pp. 23-32.

12 L. Casanova et al., From Multilatinas to Global Latinas... 
and Asia ${ }^{13}$. During that period the cost of capital fell as Multilatinas started acquiring other companies, and undertaking mergers and joint ventures with strategic partners from the markets they wanted to expand to ${ }^{14}$. Today Multilatinas are global players, but most Multilatinas still get their revenues from their home countries ${ }^{15}$.

Brazilian and Mexican Multilatinas differ from most EMNCs because their revenues derive mostly from the export of resource products, such as textiles, mechanical parts or agricultural goods. Also, construction companies were heavily financed by the state, backed many times by state-owned resource companies, such as Petrobras and VALE (a mining company that was privatized in the 1990s) in Brazil and PEMEX in Mexico ${ }^{16}$.

To understand the phenomenon of international expansion of Multilatinas, it is worth to investigate the push and pull expansion factors as proposed by Santiso ${ }^{17}$. Some authors argue that, companies internationalize due to internal factors in their home markets ${ }^{18}$, namely due to conditions such as impositions by the local government, lack of demand for their products or high market concentration. According to Hutchinson and Fleck ${ }^{19}$, pull motives make enterprises select markets abroad because of international influences; these factors are the result of policies from other countries to attract investment. Competitive pressures in Mexico and Brazil, combined with pull factors from international markets, such as sales diversification, lower labour costs in neighbouring Latin American countries and the export of resources and capabilities, meant new production facilities were some of the biggest drivers for internationalization ${ }^{20}$. Push factors such as production costs, government policies,

13 L. Casanova, Global Latinas...; A. Cuervo-Cazurra, The multinationalization of developing country MNEs: The case of multilatinas, "Journal of International Management" 2008, vol. 14(2), pp. 138-154.

14 J. Santiso, The emergence of Latin multinationals, "Cepal Review" 2008, no. 95, pp. 7-30.

15 J. Castro Olaya, I. Cuéter, Internationalization Patterns of Multilatinas, "AD-Minister" 2012, no. 21, pp. 33-54; A. Cuervo-Cazurra, Liberalización Económica y Multilatinas, "Globalization, Competitiveness and Governability" 2007, no. 1, pp. 66-86; R. Rivera, R. Soto, Empresas Multilatinas: Caracterización y Examen de Casos de Interés, 2010, http://www.tesis.uchi le.cl/tesis/uchile/2010/ec-rivera_ra/pdfAmont/ec-rivera_ra.pdf (accessed: 18.11.2019).

16 R.V. Aguilera et al., Multilatinas...

17 J. Santiso, The emergence...

18 A. Treadgold, Retailing Without Frontiers, "Retail and Distribution Management" 1988, vol. 16(6), pp. 8-12.

19 K. Hutchinson, E. Fleck, An investigation into the initial barriers to internationalization Evidence from small UK retailers, "Journal of Small Business and Enterprise Development" 2013, vol. 16(4), pp. 544-568.

20 M. Morales, Liderazgos latinoamericanos: ALBA-TCP y Unasur como opciones de la integración regional, "Confines de Relaciones Internacionales y Ciencia Política” 2013, no. 9, pp. 37-66. 
lack of resources and the increase in local production costs in Mexico and Brazil were also responsible for Multilatinas' expansion to other markets ${ }^{21}$. Additionally, the decreasing cost of capital enabled Mexican and Brazilian Multilatinas to obtain financing at lower costs, which allowed more acquisitions abroad 22 . In fact, the reasons for Mexican and Brazilian Multilatinas' internationalization vary. During the 1990s the economic liberalization was an important pull factor. The macroeconomic environment allowed Mexican and Brazilian Multilatinas to internationalize to diversify their operational risk, because the local Brazilian and Mexican economies were unstable at the time. The creation of the North American Free Trade Agreement (NAFTA) allowed Mexican Multilatinas to invest easily in the United States and Canada ${ }^{23}$.

\section{Research design}

To investigate the research gap defined, a CAGE framework was used. As mentioned by O'Farrell, Wood, and Zheng ${ }^{24}$, market selection research is essential for the outcome of an expansion to a new market and one of the tools useful in that process is CAGE model. The CAGE framework measures the Cultural, Administrative, Geographical and Economic distance between two countries ${ }^{25}$ and was introduced in order to address a company's decision-making process when developing cross-border strategies, which measures the distance between two countries taking into account Cultural, Administrative, Geographical, and Economic criteria. The distinction between bilateral and unilateral measures is also made. Bilateral measures relate to the CAGE differences between two or more countries, while unilateral describes only the characteristics of one country and do not relate that country to others. The reason for this distinction is the fact that other frameworks focus on the difference between countries according to unilateral factors, which goes in line with push and pull factors, previously mentioned.

Cultural distance is the different languages, ethnicities or social networks among people in a community, religion or national work system, or the values, norms and dispositions of a society. The characteristics of a product are different according to the country, because of the different standards for electrical goods, such

21 United Nations Conference on Trade and Development (UNCTAD), World Investment Report 2016 - Investor nationality: Policy challenges, United Nations Publication, 2016, https://unct ad.org/en/PublicationsLibrary/wir2016_en.pdf (accessed: 5.12.2019).

22 J. Santiso, The emergence...

23 J. Castro Olaya, I. Cuéter, Internationalization...

24 P. O'Farrell, P. Wood, J. Zheng, Internationalization by Business Service SMEs: An Inter-Industry Analysis, "International Small Business Journal” 2015, vol. 16(2), pp. 109-128.

25 P. Ghemawat, Distance Still Matters, "Harvard Business Review" 2001, no. 79, pp. 137-147. 
as household appliances, or different packaging 26 . Administrative criteria mention the lack or existence of colonial ties between countries, the existence or nonexistence of a regional trading bloc such as the European Union, NAFTA or MERCOSUL, or the differences in terms of legal systems or political hostility between the country of origin and the country the company wants to expand into ${ }^{27}$. Being part of a closed economy or a home bias towards investment makes individuals and companies invest more in their own country. Products or services affected by administrative criteria are those with a high involvement of the government, including producers of necessity goods, such as electricity, discoverers of natural resources, such as iron ore, oil or natural gas, agricultural companies or crucial companies for national security, such as telecommunications companies ${ }^{28}$.

Geographical criteria form another dimension described in the CAGE framework. The distance between countries, the difference in time zones between countries and the existence of shared borders are very relevant and facilitate, or not, the occurrence of trade between two or more countries. Unilaterally, if a country is landlocked this will have a negative influence on trade, as will poor internet accessibility or weak transportation links with other geographies ${ }^{29}$. Perishable or fragile products as fruit, tiles or glass, financial services that require good communication and connectivity or the transportation of goods such as cement that require extensive logistics are greatly affected by geographical distance ${ }^{30}$.

The economic criteria described by Ghemawat ${ }^{31}$ mention the difference in resources and the available infrastructure in two or more countries and the size and evolution of their gross domestic product (GDP) and GDP per capita. The economic distance between two countries also shows the differences in the cost and quality of the resources available (i.e. natural, human, financial and information resources) and therefore affects the workforce and other company costs ${ }^{32}$.

This study will use a case research approach, considering that we are trying to understand if a specified framework applies to Multilatinas from Brazil and

26 Ibidem.

27 P. Ghemawat, Differences Across Countries: The CAGE Distance Framework. Redefining global strategy: crossing borders in a world where differences still matter, Harvard Business School, Boston 2007.

28 P. Ghemawat, The globalization of business education: through the lens of semiglobalization, "Journal of Management Development" 2008, vol. 27(4), pp. 391-414.

29 P. Ghemawat, S. Altman, Geographic Distance and Regionalization, [in:] P. Ghemawat (ed.), The Laws of Globalization and Business Applications, Cambridge University Press, Cambridge 2016, pp. 321-357.

30 P. Ghemawat, Differences Across Countries...

31 P. Ghemawat, Distance...

32 P. Ghemawat, Differences Across Countries... 
Mexico. Available studies in these two types of Multilatinas will be used along with secondary data derived from companies from those countries: "Secondary data can include any data that are examined to answer a research question other than the question(s) for which the data were initially collected" 33 . Statistical information about a number of organizations or geography is also considered as a type of secondary data ${ }^{34}$. Using the results from the America Economia Top 100 ranking, it is possible to assess where Mexican and Brazilian Multilatinas expanded and relate that to the literature and data reports previously investigated for the research, in order to deduce possible reasons for the expansion into certain locations instead of others. The computation of the CAGE framework using the CAGE comparator developed by Ghemawat ${ }^{35}$ will permit us to see which countries have the lowest CAGE distance to Brazil and to Mexico.

\section{Findings and discussion}

When expanding to new markets, companies have two different approaches. According to Bradley ${ }^{36}$, international market behaviour can be systematic or opportunistic. Brazilian and Mexican Multilatinas expand using these two approaches.

The opportunistic approach is when companies grasp an opportunity in a foreign market. This selection occurs following a stimulus, like a request for prices, product information or media information ${ }^{37}$, and has been made by Latin American companies since their existence. They have been opportunistic buyers of industrial assets when many foreign MNCs withdrew from Central and South America because of unstable political and economic circumstances, and Multilatinas took that chance to expand their market position. When using this approach the managers of Multilatinas already have experience in the selection of international markets and networking plays a vital role. The higher the experience of the manager in internationalization, the higher the chance of using an opportunistic approach ${ }^{38}$.

The systematic approach happens when there is a method or logical process of choosing a new market. Systematicity is a way of market planning to accomplish

33 T.P. Vartanian, Secondary Data Analysis, Oxford University Press, New York 2010, p. 3.

34 S. Boslaugh, Secondary Data Sources for Public Health: A Practical Guide, Cambridge University Press, New York 2007.

35 P. Ghemawat, Differences Across Countries...

36 F. Bradley, International Marketing Strategy, Prentice Hall, Harlow 1991.

37 Ibidem.

38 K. Hutchinson et al., Internationalization Motives and Facilitating Factors: Qualitative Evidence from Smaller Specialist Retailers, “Journal of International Marketing” 2007, vol. 15(3), pp. 96-122. 
the company's marketing goals ${ }^{39}$. Multilatinas investigate the most appropriate markets as well the industry and the firm's sales potential in a region, taking into account the company's reality and objectives, according to Hutchinson and Fleck ${ }^{40}$.

The conceptual framework outlined in Table 1 describes the CAGE criteria and how they are related to the international market selection process. It illustrates whether Mexican and Brazilian Multilatinas are indeed affected by the criteria described by CAGE approach.

Table 1. Characteristics from Brazil and Mexico that allowed or made difficult the expansion to other markets

\begin{tabular}{|c|c|}
\hline Brazil & Mexico \\
\hline \multicolumn{2}{|c|}{ Cultural criteria } \\
\hline $\begin{array}{l}\text { Portuguese speaking country with the } \\
\text { largest population in the world } \\
\text { - The only country that speaks Portuguese } \\
\text { in South America Former colony ties with } \\
\text { Portugal and former Portuguese colonies } \\
\text { - High diversity of ethnicities in Brazil } \\
\text { allows companies to offer a diverse range } \\
\text { of products and services all around the } \\
\text { world }\end{array}$ & $\begin{array}{l}\text { - People speak Spanish as in most of Latin } \\
\text { - Fmerica } \\
\text { - Former colony ties with Spain and other } \\
\text { - There are many Mexican and of Mexican } \\
\text { origin living in the United States } \\
\text { - Mexico is a predominantly Catholic country } \\
\text { - Spanish speaking country with the largest } \\
\text { population }\end{array}$ \\
\hline \multicolumn{2}{|c|}{ Administrative criteria } \\
\hline $\begin{array}{l}\text { - High levels of corruption and government } \\
\text { influence } \\
\text { - High rates of crime } \\
\text { - Belongs to Mercosul } \\
\text { - High tariffs for imports of certain goods and } \\
\text { services } \\
\text { - Ranked } 125 \text { th on the Easiness } \\
\text { to do Business ranking }\end{array}$ & $\begin{array}{l}\text { - High levels of corruption and government } \\
\text { influence } \\
\text { - High tariffs for imports of certain goods and } \\
\text { services } \\
\text { - Belongs to NAFTA } \\
\text { - High rates of crime } \\
\text { - Ranked 49th on the Easiness to do Business } \\
\text { Ranking }\end{array}$ \\
\hline \multicolumn{2}{|c|}{ Geographical criteria } \\
\hline $\begin{array}{l}\text { - Biggest Country in Latin America } \\
\text { - Borders most South American countries } \\
\text { and has access to the Atlantic Ocean } \\
\text { - The remoteness of Amazon Forest difficult } \\
\text { transportation to many border countries } \\
\text { - Decreasing of commodity prices have been } \\
\text { damaging the Brazilian Economy }\end{array}$ & $\begin{array}{l}\text { - 3rd biggest country in Latin America } \\
\text { in terms of geographical size } \\
\text { - Borders the United States, Belize and } \\
\text { Guatemala } \\
\text { - Access to the Caribbean Sea and the } \\
\text { Pacific Ocean } \\
\text { - Geographically close to most Central } \\
\text { American countries, the United States } \\
\text { and Canada } \\
\text { - The decrease in commodity prices has been } \\
\text { damaging the Mexican Economy }\end{array}$ \\
\hline
\end{tabular}

39 F. Bradley, International Marketing...

40 K. Hutchinson, E. Fleck, An investigation... 


\begin{tabular}{|c|c|}
\hline Brazil & Mexico \\
\hline \multicolumn{2}{|c|}{ Economic criteria } \\
\hline $\begin{array}{l}\text { - Biggest GDP in Latin America } \\
\text { - Very rich in natural resources as oil, copper, } \\
\text { gold and silver } \\
\text { - Low Income per Capita } \\
\text { - The huge gap between low and high- } \\
\text { income citizens } \\
\text { - The government has been privatizing many } \\
\text { Brazilian companies } \\
\text { - Brazil is the country with the highest } \\
\text { number of Multilatinas }\end{array}$ & $\begin{array}{l}\text { - } 2 \text { nd Biggest GDP in Latin America } \\
\text { - Low Income per capita, but higher than } \\
\text { most central American countries \& the } \\
\text { Caribbean } \\
\text { - Many Mexican companies have been } \\
\text { privatized by the government } \\
\text { - Mexico country with the highest number } \\
\text { of Multilatinas after Brazil }\end{array}$ \\
\hline
\end{tabular}

Source: own work.

Cultural distance affects the preference for a product or service, but it affects it differently according to the type of good or service. For example, cultural distance matters more when products have high linguistic content (TV programs) or have high importance for cultural identity, as traditional dishes from a certain country or region ${ }^{41}$. Companies start their internationalization by entering markets they comfortably comprehend better, and there they will sense better opportunities because their perceived market uncertainty is lower ${ }^{42}$. Also, cultural similarities generate better marketing for companies.

For Casanova 43 , "natural markets" have common historical links and languages, as well as geographical proximity. Multilatinas expand to bordering countries because of the same language and a similar culture, according to Cuervo-Cazurra ${ }^{44}$. Latin America has been a natural market for Latin American companies that opt to expand to neighbouring countries, or even Mexican companies expanding to the United States due to the Hispanic population living there. The US market is a place where Mexican companies can deal with the familiarity of consumer tastes. According to Frankel and Rose ${ }^{45}$, countries that share the same language have $200 \%$ more trade than others that do not have a common language. Multilatinas started competing in markets with a linguistic and cultural affinity as a way to test out the process of internationalization ${ }^{46}$.

41 P. Ghemawat, Distance...

42 E. Brewer, On Lending to Small Firms, "Journal of Small Business Management" 2007, vol. 45(1), pp. 42-46.

43 L. Casanova, Global Latinas...

44 A. Cuervo-Cazurra, Multilatinas.

45 J. Frankel, A. Rose, Estimating the Effect of Currency Unions on Trade and Output, "NBER Working Paper Series" 2000, no. 3, pp. 1-51.

46 L. Casanova et al., From Multilatinas to Global Latinas... 
Analysing the results from the Top 100 America Economia ranking for 2017, it is possible to identify that Mexican companies have operations in regions whose countries speak the same language, Spanish. That is, $88 \%$ of Mexican Multilatinas from the ranking have expanded to South America (Brazil not included), 73\% to Central America and the Caribbean, and $81 \%$ to the United States, a country with a huge Hispanic community that shares a border with Mexico. The language's influence in Brazil is not perceivable in Latin America, since it is the only Latin American country where people speak Portuguese and not Spanish. Mexico also shares the same colonizer, Spain, as most countries from Central America, the Caribbean and South America, and it could be the reason for a high number of Mexican Multilatinas in these areas. According to Frankel and Rose ${ }^{47}$, trade between two countries with the same colonizer is $190 \%$ higher.

Mexican and Brazilian Multilatinas expand less to regions where a common language and any colony/colonizer relationships do not exist, such as the Asia $\mathrm{Pa}-$ cific, West and Central Asia and Oceania. Mexican Multilatinas do not expand much to Africa - only $8 \%$ while $35 \%$ of Brazilian Multilatinas choose that continent. This might be happening because African countries such as Angola, Mozambique, S. Tomé and Principe and Guinea-Bissau speak Portuguese and were also former colonies of the Portuguese Empire.

A small percentage of Brazilian Multilatinas expand to Central America and the Caribbean (around 19\% against 73\% of Mexican Multilatinas in that region) is the fact that the cultural distance between Mexico and Central America and the Caribbean is smaller than between Brazil and Central America and the Caribbean. Brazil was colonized by the Portuguese, while Central America and the Caribbean were colonized by the English, French and Spanish, so the language is different and they do not have former colonial ties. The language might not be the strongest factor in South America, as Brazilian Multilatinas are more present in countries where Spanish is spoken, with $100 \%$, contrasting with Mexican Multilatinas, with $88 \% 48$. Religion, social norms and beliefs are similar throughout Latin America, but are very different when considering other geographical locations such as West and Central Asia, where the main religion is Islam, or the Asia Pacific, where people have a different moral code than in Latin America.

When analysing the administrative criteria, it is worth mentioning that companies from former colonizers are ten times more likely to trade with companies from their colonies ${ }^{49}$. This fact can explain the high percentage of Brazilian Multilatinas

47 J. Frankel, A. Rose, Estimating the Effect of Currency Unions...

48 America Economia, Top 100 Ranking 2016, 2016, https://rankings.americaeconomia.com /2016/multilatinas/ (accessed: 20.11.2019).

49 P. Ghemawat, Distance... 
that have operations in Europe (92\%), as Brazil was a former Portuguese colony. Mexico was a former Spanish colony, but the percentage of Mexican Multilatinas in Europe is much lower: around 54\%. So the colony-colonizer relationship factor is not always a rule. According to the ranking presented by World Bank ${ }^{50}$, Brazil and Mexico are not very well ranked in 2018, compared to New Zealand (1st), the United States (6th) or some Asian Tigers such as Hong Kong (5th), South Korea (4th) and Singapore (2nd). Mexico occupies the 50th position and is the highestplaced Latin American country, while Brazil is in 125th place out of 191 countries. It is worth mentioning that the creation of barriers, nontariff barriers, quotas or embargoes by Latin American governments from countries such as Brazil, Argentina, Cuba, Colombia and Venezuela has not been a problem for the creation of successful Multilatinas and their expansion into other Latin American countries $^{51}$. The high ease of doing business in the United States, as well as in most European countries, might be one of the reasons why Brazilian and Mexican Multilatinas have expanded there.

Many Asia Pacific countries have a very good classification in the Easiness to do Business ranking, and therefore it could explain the high percentage of Brazilian Multilatinas in the Asia Pacific (69\%). The highest number of people of Japanese origin outside Japan is in Brazil ${ }^{52}$, even if the two countries are very far from each other geographically and the cultural distance between its people is very low (since language, culture, food are very different). This factor might have influenced Brazilian companies' to expand into Japan. Brazil belongs to the BRIC grouping, as does China, and they have political and economic ties ${ }^{53}$.

The geographical distance influences the communication and transportation costs, especially when Multilatinas have to deliver bulky goods to other locations, or need a high degree of coordination between employees. The further someone is from a country, the harder it is to do business there ${ }^{54}$. But distance is also about accessibility; access to the ocean, for example, is a way of boosting trade between countries. If a country has a common border with another one, the trade between those countries is expected to be $80 \%$ higher. The same way, two countries

50 World Bank, Ease of Doing Business rankings, http://www.doingbusiness.org/rankings (accessed: 5.12.2019).

51 ECLAC U.N., Statistical Yearbook for Latin America and the Caribbean, 2007, https://www.ce pal.org/en/publications/922-anuario-estadistico-america-latina-caribe-2007-statistical -yearbook-latin-america (accessed: 19.09.2019).

52 Central Intelligence Agency, CIA World Fact Book, 2017, https://www.cia.gov/library/pub lications/resources/the-world-factbook/index.html (accessed: 20.11.2019).

53 United Nations Conference on Trade and Development (UNCTAD), World Investment Report...

54 P. Ghemawat, Distance... 
with access to the ocean see a $50 \%$ increase in trade among them ${ }^{55}$. The transportation and communications infrastructures between countries are also important ${ }^{56}$ and contribute for the explanation of some expansion patterns.

All Brazilian companies from the ranking are present in the rest of South America, but that does not happen with Mexican companies, $88 \%$ of whom are in the South American region (Brazil not included). Probably due to higher geographical proximity, Brazilian companies are more attracted to South American countries than Mexican ones, as Brazil shares a border with all South American countries except Ecuador and Chile. Its border is $15,719 \mathrm{~km}$ long and the Brazilian territory occupies $48 \%$ of South America ${ }^{57}$. The only major obstacle that might hinder the connection between Brazil and other South American countries, such as Venezuela, Colombia and Peru, is the immense Amazon rainforest. Mexico borders the United States, Belize and Guatemala, but is geographically close to most Central American countries through the Caribbean Sea.

It is possible to conclude that Brazilian and Mexican multinationals have more operations in regions from the American continent than regions on other continents. The only exception is the low presence of Brazilian Multilatinas in Central America and the Caribbean. Mexican Multilatinas expand more to South American countries (excluding Brazil) than to Central America and the Caribbean, meaning that geographical distance criteria are not the most important, as no border is shared between Mexico and South America.

According to the Boston Consulting Group ${ }^{58}$, Brazilian Multilatinas are more focused on South American countries. On the other hand, Mexican Multilatinas are more concentrated in the United States, due to geographical proximity and other factors. But in the Top 100 America Economia ranking from 2016, which only considers 100 Multilatinas, Brazilian companies are more present in the United States than Mexican ones, so geographical criteria are not, again, the main explanation for this market selection.

According to Frankel and Rose ${ }^{59}$, there are economic factors that boost trade between countries. Those with weak infrastructure can damage cross-border economic activity ${ }^{60}$, which could explain the low percentage of Mexican and Brazilian multinationals with operations in Africa ( $8 \%$ and $35 \%$, respectively) and the preference for the European continent and even for countries in the Asia Pacific.

55 J. Frankel, A. Rose, Estimating the Effect of Currency Unions...

56 P. Ghemawat, Distance...

57 Central Intelligence Agency, CIA World Fact Book.

58 Boston Consulting Group, The 2009 BCG Multilatinas, Boston 2009.

59 J. Frankel, A. Rose, Estimating the Effect of Currency Unions...

60 P. Ghemawat, Distance... 
Companies do not usually like investing in countries with high levels of corruption, which might deter Multilatinas from the African continent, where bribery and corruption are more evident. However that seems not to deter Multilatinas from investing in other Latin American countries ${ }^{61}$. Rich countries also trade more among themselves, as there is a positive correlation between GDP per capita and the international trade of a country. Poor countries also trade more with rich countries than with each other ${ }^{62}$, and in fact, not counting the Latin American region, Multilatinas have more operations in the United States and Europe compared to other regions around the world.

Using the CAGE comparator developed by Ghemawat ${ }^{63}$, the distance between Mexico and other countries according to the CAGE distance for the commerce of merchandise was calculated. The same calculation was also done for Brazil. Most countries with the lowest CAGE distance to Mexico speak the same language (Spanish), have colonial ties (were part of the Spanish Empire) or belong to the same continent. The two countries with the lowest CAGE distance border Mexico (Guatemala and Belize). Only 8 of the first 25 countries with the lowest CAGE distance for exports of merchandise do not speak a different language to Mexico. In addition, the other two members of NAFTA (the United States and Canada) have a low CAGE distance with Mexico.

In case of Brazil, nine countries with the lowest CAGE distance share a border with Brazil, Chile in 10th place belongs to the same continent, and Portugal in 11th place shares the same language and has colonial ties with Brazil. Most countries with the lowest CAGE distance from Brazil speak the same language (Portuguese). Most countries (such as Portugal, Angola, and Mozambique) from the former Portuguese Empire are on the list of countries. All the first nine countries with the lowest CAGE distance from Brazil share a common border with the country. Also, the other members of MERCOSUL (Argentina, Paraguay, and Uruguay) are the countries with the lowest CAGE distance from Brazil.

\section{Theoretical findings}

The contribution of this paper is a conceptual analysis of the application of the CAGE framework, exploring external Cultural, Administrative, Geographical, and Economic factors Ghemawat ${ }^{64}$. We tried to understand if that framework

61 United Nations Conference on Trade and Development (UNCTAD), World Investment Report...

62 P. Ghemawat, Distance...

63 P. Ghemawat, Differences Across Countries...

64 P. Ghemawat, Distance... 
could be used to evaluate how its factors influence international market selection for Mexican and Brazilian Multilatinas. It is worth mentioning that Multilatinas are different to multinationals from the developed world and emerged later than those in Asian developing countries, such as South Korea, China and Taiwan. They are mostly family-owned conglomerates and many of them are or were state-owned. The research conducted, through secondary data analysis, made it possible to conclude that Multilatinas expanded mostly into bordering countries. CAGE criteria influence a Multilatina's expansion, as results from the CAGE framework for merchandise exports for Brazil and Mexico showed that countries with the lowest CAGE distance belong to the regions where Multilatinas expanded the most in general. Brazilian Multilatinas from the top 100 sample expanded more into the United States than the Mexican ones, which was one of the most surprising findings, even if the sample only has the largest Multilatinas in Latin America and does not consider the small and medium-sized companies from the region. Brazilian companies did not expand much into Central American countries and the Caribbean, even those with similar cultures, but different languages and a lack of economic interest could be a reason for this. Brazilian and Mexican multinationals have different expansion patterns. Brazilian Multilatinas are more predominant in Europe and in the Asia Pacific than Mexican. Mexican companies expand more to Central America and the Caribbean.

The CAGE characteristics of Brazil and Mexico have some differences, on one hand, but also some similarities, on another hand. Culturally speaking, Brazil and Mexico speak different languages and belong to different continents. Administratively, though, both countries experience high levels of corruption and rates of crime. Multilatinas from these countries also pay high tariffs for the import of goods and services. Geographically Brazil and Mexico belong to different continents and border different countries.

Thus, the main theoretical contribution of the study presented is the confirmation that CAGE framework assist in explaining the geographical pattern of international market selection decisions of Multilatinas and can be used as a predictor for other countries.

\section{Limitations and further research}

The research methodology only analysed secondary data and did not use other data-collection methods, which could have led to complementary findings ${ }^{65}$. Additionally, this study's sample was based on only 100 Multilatinas from the America

65 S. Boslaugh, Secondary Data Sources... 
Economia ranking from 2017. So it did not include all Multilatinas and no small and medium-sized companies from Latin America. The CAGE framework only showed the CAGE distance for the exports of merchandise, also limiting the research findings.

The process of market selection made by Multilatinas should be tested for a specific sector, to evaluate how CAGE factors influence Multilatinas' market selection. Different companies' size should also be considered. To this aim, interviews should also be performed as additional method of data collection. Another avenue of research would be investigating European countries to verify whether the same insights can be proposed.

The research presented provided contribution to the literature on recent trends in FDI and that could be further developed as suggested by Kyrkilis and Grujic ${ }^{66}$. An interesting issue would also include investigating the usefulness of the other models described - i.e. Uppsala model of the internationalization process, for contemporary emerging MNEs which may range from more modern retailers to techbased firms. It would be interesting to compare the findings with those presented in the study described, where the CAGE framework was investigated.

\section{References}

Aguilera R.V., Ciravegna L., Cuervo-Cazurra A., Gonzalez-Perez M., Multilatinas and the internationalization of Latin American firms, "Journal of World Business" 2017, vol. 52(4), pp. 447-460.

America Economia, Rankings, 2017, https://www.americaeconomia.com/rankings (accessed: 1.02.2020).

America Economia, Top 100 Ranking 2016, 2016, https://rankings.americaeconomia.com/2016 /multilatinas/ (accessed: 20.11.2019).

Boslaugh S., Secondary Data Sources for Public Health: A Practical Guide, Cambridge University Press, New York 2007.

Boston Consulting Group, The 2009 BCG Multilatinas, Boston 2009.

Bradley F., International Marketing Strategy, Prentice Hall, Harlow 1991.

Brewer E., On Lending to Small Firms, "Journal of Small Business Management" 2007, vol. 45(1), pp. 42-46.

Casanova L., Global Latinas: Latin America's Emerging Multinationals, Palgrave Macmillan, London 2009.

Casanova L., Fraser M., Hoeber H., Golstein A., Godinho M.M., Molina R., Almeida A., From Multilatinas to Global Latinas: The New Latin American Multinationals, IDB Working Paper Series, 2009, pp. 4-234.

66 D. Kyrkilis, N. Grujic, Do National Borders Matter? Distance as FDI Determinant: The Case of Serbia, [in:] S. Roukanas, P. Polychronidou, A. Karasavvoglou (eds), The Political Economy of Development in Southeastern Europe. Contributions to Economics, Springer, Cham 2018, pp. 35-50. 
Castro Olaya J., Cuéter I., Internationalization Patterns of Multilatinas, “AD-Minister” 2012, no. 21, pp. 33-54.

Central Intelligence Agency, CIA World Fact Book, 2017, https://www.cia.gov/library/publications /resources/the-world-factbook/index.html (accessed: 20.11.2019).

Chattopadhyay A., Batra R., Ozsomer A., The New Emerging Market Multinationals - Four Strategies for Disrupting Markets and Building Brands, McGraw-Hill Education, New York 2012.

Cuervo-Cazurra A., Liberalización Económica y Multilatinas, "Globalization, Competitiveness and Governability" 2007, no. 1, pp. 66-86.

Cuervo-Cazurra A., Multilatinas, "Universia Business Review” 2010, no. 25, pp. 14-33.

Cuervo-Cazurra A., The multinationalization of developing country MNEs: The case of multilatinas, "Journal of International Management" 2008, vol. 14(2), pp. 138-154.

ECLAC U.N., Statistical Yearbook for Latin America and the Caribbean, 2007, https://www.cepal .org/en/publications/922-anuario-estadistico-america-latina-caribe-2007-statistical-year book-latin-america (accessed: 19.09.2019).

Frankel J., Rose A., Estimating the Effect of Currency Unions on Trade and Output, "NBER Working Paper Series" 2000, no. 3, pp. 1-51.

Ghemawat P., Differences Across Countries: The CAGE Distance Framework. Redefining global strategy: crossing borders in a world where differences still matter, Harvard Business School, Boston 2007.

Ghemawat P., Distance Still Matters, “Harvard Business Review” 2001, no. 79, pp. 137-147.

Ghemawat P., The globalization of business education: through the lens of semiglobalization, "Journal of Management Development" 2008, vol. 27(4), pp. 391-414.

Ghemawat P., Altman S., Geographic Distance and Regionalization, [in:] P. Ghemawat (ed.), The Laws of Globalization and Business Applications, Cambridge University Press, Cambridge 2016, pp. 321-357.

Guillén M., García-Canal E., The American Model of the Multinational Firm and the 'New' Multinationals from Emerging Economies, "Academy of Management Perspectives" 2009, vol. 23(2), pp. 23-35.

Hutchinson K., Fleck E., An investigation into the initial barriers to internationalization Evidence from small UK retailers, "Journal of Small Business and Enterprise Development" 2013, vol. 16(4), pp. 544-568.

Hutchinson K., Alexander N., Quinn B., Doherty A.M., Internationalization Motives and Facilitating Factors: Qualitative Evidence from Smaller Specialist Retailers, "Journal of International Marketing" 2007, vol. 15(3), pp. 96-122.

Johanson J., Valhne J., The Internationalization Process of a Firm - a Model of Knowledge, Foreign and Increasing Market Commitments, "Journal of International Business Studies" 1977, vol. 8(1), pp. 23-32.

Kyrkilis D., Grujic N., Do National Borders Matter? Distance as FDI Determinant: The Case of Serbia, [in:] S. Roukanas, P. Polychronidou, A. Karasavvoglou (eds), The Political Economy of Development in Southeastern Europe. Contributions to Economics, Springer, Cham 2018, pp. 35-50.

Morales M., Liderazgos latinoamericanos: ALBA-TCP y Unasur como opciones de la integración regional, "Confines de Relaciones Internacionales y Ciencia Política" 2013, no. 9, pp. 37-66.

O'Farrell P., Wood P., Zheng J., Internationalization by Business Service SMEs: An Inter-Industry Analysis, "International Small Business Journal” 2015, vol. 16(2), pp. 109-128.

Rivera R., Soto R., Empresas Multilatinas: Caracterización y Examen de Casos de Interés, 2010, http://www.tesis.uchile.cl/tesis/uchile/2010/ec-rivera_ra/pdfAmont/ec-rivera_ra.pdf (accessed: 18.11.2019).

Santiso J., The emergence of Latin multinationals, “Cepal Review” 2008, no. 95, pp. 7-30. 
Treadgold A., Retailing Without Frontiers, “Retail and Distribution Management” 1988, vol. 16(6), pp. 8-12.

United Nations Conference on Trade and Development (UNCTAD), World Investment Report 2016 - Investor nationality: Policy challenges, United Nations Publication, 2016, https://unctad .org/en/PublicationsLibrary/wir2016_en.pdf (accessed: 5.12.2019).

Vartanian T.P., Secondary Data Analysis, Oxford University Press, New York 2010.

World Bank, Ease of Doing Business rankings, http://www.doingbusiness.org/rankings (accessed: 5.12.2019).

\section{Abstract}

Multilatinas have become a phenomenon that has caught the attention of many authors and researchers around the world. This paper was developed to understand their international market selection process and the challenges they face. We hypothesized that these companies ground their international expansion on the basis of physical proximity. The CAGE framework developed by Ghemawat measures the distance between two countries according to Cultural, Administrative, Geographic and Economic criteria and was the main indicator for this research. The literature review allowed for the exploration of concepts related to Multilatinas' expansion, such as emerging market multinational companies management, internationalization process, market selection, and the CAGE framework. The systematic and opportunistic way of selecting markets were also studied in the development of a framework used to understand how managers from Mexican and Brazilian Multilatinas decide on market selection and which factors they take into account in that decision process. It was possible to verify that countries where Mexican and Brazilian Multilatinas expand are the ones with the lowest overall CAGE distance.

Keywords: Emerging Market Multinationals, Multilatinas, Market Selection Challenges, CAGE model 